\title{
Ending Poverty: Factors That Might Influence the Achievement of Sustainable Development Goals (SDGs) in Indonesia
}

\author{
Saddam Rassanjani \\ Graduate of Master Public Policy and Management, University of Glasgow
}

Received: May 14, 2018 Accepted: August 9, 2018 Online published: August 14, 2018

doi:10.5296/jpag.v8i3.13504ＵRL: https://doi.org/10.5296/jpag.v8i3.13504

\begin{abstract}
The eradication of poverty is the top priorities of the Indonesian government. This study examines the poverty reduction program in Indonesia within the framework of the global development agenda that is the Sustainable Development Goals (SDGs), and the discussion focused on Goal 1 (No Poverty). This qualitative research offers a critical review of Goal 1 the SDGs in Indonesia by outlined some potential factors in achieving this gracious mission. And it can be highlighted that; converging of agendas; a collaborative-partnerships; well-established poverty reduction program, alternative funding like Zakat; the innovation of database; and learning from the best practice; are likely will be the key factors that might influence the achievement of SDGs.
\end{abstract}

Keywords: Indonesia, Poverty, SDGs, MDGs

\section{Introduction}

Poverty becomes an encumbrance for developing countries regarding their efforts to upgrade their status to that of a developed country. The existence of extreme poverty in several countries led to the foundation of a programme initiated by the United Nations (UN) and its member states. In September 2000, at the United Nations Millennium Summit in New York, many countries announced a series of Millennium Development Goals (MDGs) that were to be achieved by 2015 to address key global development challenges. This includes an expressed aim to reduce by half the number of people across the world suffering from poverty. However, according to the global monitoring report, this target was achieved by 2010, much quicker than expected (World Bank, 2013). While the MDGs appear to have succeeded, there are ongoing and significant issues that may interfere with efforts to improve and maintain this performance, such as environmental degradation.

Whilst the global population continues to grow, the natural resources that support human life, 
such as energy, water, and food are becoming increasingly scarce. This scarcity is exacerbated by the problem of global warming with all its attendant implications, such as an increased likelihood of storms, floods, and droughts. If these environmental challenges are not controlled, they may, in turn, undermine the achievement of the MDGs. Therefore, the world needs to establish a new development model that can address this challenge. In response, the Rio de Janeiro Earth Summit in 2012 inspired the birth of (SDGs), a sustainable development model that may help resolve world's problems following the end of the MDGs. The SDGs have broader objectives and are a sustainable approach with 17 goals, 169 targets, and 232 indicators (UN, 2017). This contrasts with the MDGs which focused on just eight goals, 18 targets, and 48 indicators (UN, 2000). Thus, the SDGs are intended to replace the MDGs; however, it cannot yet be known whether the achievement of the SDGs will surpass that of the MDGs, but it is likely that the existence of SDGs will at least mask the weaknesses of the MDGs.

Kumar et al. (2016) expressed deep appreciation for the performance of the United Nations and the organisations under its jurisdiction, which have been very active in many international development programmes since the late 1940s. For them, the MDGs and SDGs are two programmes amongst many and offer the most recent evidence of the seriousness of the United Nations in dealing with development issues. And it can be said that the SDGs is fully committed to the implementation of a national development agenda, mainly poverty alleviation program for all levels of society which will achieve substantial coverage of poor and vulnerable communities across the world by 2030, as it has stated in Goal 1-Target 3. And this is why governments are very optimistic regarding SDGs, as they recognise its intention to expand and strengthen an ending poverty programme.

The enthusiasm for SDGs is not just expressed by the government, many experts and researchers have also been vying to predict the fate of SDGs. Although the main agenda of SDGs is to end poverty, it also contain a number of diverse goals that are interconnected, which affects the repertoire of research conducted on SDGs from various perspectives and areas such as health (Proulx, Ruckert and Labonté, 2017), gender (Onditi and Ondera, 2016), climate change (Salleh, 2016), human rights (Lueddeke, 2015), energy (Weitz, Nilsson and Davis, 2014) and many others. Meanwhile, Liu et al. (2015) and Kamruzzaman (2016) are examples of researchers who directly address the topic of SDGs and poverty. However, none of all those researches promoted Indonesia as their main object of research, and it is hard to find study that examined the poverty reduction agenda in Indonesia within the framework of the SDGs. Therefore, by more focus on Goal 1 (No poverty) only, this research will address what factors that might affect the accomplishment of the SDGs in Indonesia? In so doing, this research may serve as an indicator or evaluation of the achievement of SDGs in Indonesia.

\section{Methodology}

This research is based on the qualitative data. The most crucial consideration when collecting data is concerns to the selection of participants, because to obtain precise and accurate data it is necessary to recruit participants who have the competence and the information needed. Therefore, the sampling technique that will be used by the researcher in this study is that of a 
purposive sample. Maxwell (1997) argued that a purposive sample is a technique that involves recruiting a sample with certain characteristics, thus only respondents who possess certain skills, knowledge, opinions or abilities will be targeted. Thus, it is necessary to identify respondents who can help to address the problems above. And to assist the researcher in finding the desired respondents, specific criteria were used as a reference point. These are: (i) Being able to identify the poverty problem in Indonesia, (ii) At least knowing the achievements of the MDGs, and ongoing SDGs, (iii) Engaging directly with the coordinator or person in charge of the programme; (iv) Overseeing policies, including government policy. In line with the above parameters, the following can be considered as participants; members of government, researchers, academics, and NGOs.

Regarding the number of respondents, Patton (2002), stated that qualitative research is flexible in nature. Therefore, there is no definite rule concerning the number of participants who can be recruited. The number depends largely on what is considered useful and can be achieved given the available time and resources. In this research, each element required 2-3 respondents, so the overall number of respondents fell between 8-12 people. Moreover, considering the SDGs is relatively new and unknown in Indonesia, there was likely to be fewer respondents than this, but certainly every element will be represented.

Bryman (2012) argues that the collection of qualitative data can be conducted through observation, interviews, focus groups discussion, conversations, and documentation. In this study, the researcher collected data using interviews and documents. Interviews were therefore conducted using a semi-structured technique based on previously prepared interview questions. By using open-ended questions, the researcher enabled the interviewee to respond without having to answer in a certain way. Thus, the researcher acquired the knowledge, experience, opinions or perceptions of the interviewee, leading to rich and detailed information.

The use of documents as data covers a vast range of different source material. Documents can include: personal documents obtained from various sources, official documents from both state and private sources, mass media output, and internet resources (Bryman, 2012). However, these documents should be authentic, credible, representative, and meaningful (Scott, 1990). Thus, documents are one of the data sources that can be clearly accounted for, provided they are qualified.

\section{Findings}

Poverty has been positioned as the principal goal in the last two global development agendas. In the MDGs, poverty and hunger were combined in Goal 1, whereas in SDGs they were separated, with poverty remaining as Goal 1, and hunger listed as Goal 2. Therefore, by this transformation of goals it can be said that the SDGs constitute a new type of global development programme aimed at tackling chronic poverty following the success of MDGs, even though not all countries received the benefits of this success.

As a developing country with one of the highest population densities in the world, Indonesia has continued to struggle with poverty, although the situation is steadily improving. 
According to the most recent data from Badan Pusat Statistik (BPS), in September 2017 the number of families in Indonesia with per capita expenses per month that were below the poverty line reached 26.58 million (10.12 percent), compared to September 2011 where the number of poor families stood at 30.01 million (12.36 percent). Thus, according to the data, the Indonesian poverty rate continues to decline yearly. Current conditions are much better than six years ago, and if the government can maintain this performance, the mission to reach zero poverty in 2030 is likely to be realised.

According to World Poverty Clock, the sites that provides real-time poverty estimates and monitors progress against ending extreme poverty for almost every country in the world until 2030, Indonesia is on the right track for SDGs achievement and have capacity to escape from poverty by 2030. That finding is not startled to hear because the government is solemn to accomplish the SDGs, and there are many steps that government has been taking, one of them is appointed Badan Perencanaan dan Pembangunan Nasional (Bappenas) to coordinate the SDGs in Indonesia. This agency is responsible for formulating the national action plan that will oversee the successful implementation of SDGs, such as integrating SDGs into national action plans which could make the implementation of existing poverty alleviation programmes more effective. Moreover, there are six key factors that essentially might accelerate the achievement of SDGs, namely converging of agendas; a collaborative-partnerships; well-established poverty reduction program, alternative funding like Zakat; the innovation of database; and learning from the best practice.

\subsection{Converging of Agendas}

A year after Indonesia's elected president Joko Widodo was sworn in for the 2014-2019 period, the leaders of $193 \mathrm{UN}$ member states including Indonesia finally decided to adopt SDGs as a new milestone in the international community's commitment to a global development agenda, and thus they decided to continue achieving the MDGs from 2015 through to 2030. Moreover, before the SDGs were included in the priorities of Indonesia's development agenda, President Joko Widodo had already implemented a national development programme called Nawa Cita, which consisted of nine development priorities. Nawa Cita itself is incorporated into the national medium-term development plan called Rencana Pembangunan Jangka Menengah (RPJMN) 2015-2019, which was launched on 8 January 2015. This means that, before the adoption of SDGs, Indonesia has followed medium-term development guidelines. Substantively, RPJMN and SDGs have many similarities, not in technical terms (targets and indicators) but in terms of goals. Regarding the implementation opportunities, I think the chance is huge because we have connected the achievement of national development with the realisation of SDGs (V. Yulaswati, personal communication, July 19, 2017). Table 1 below show the form of syncretism between RPJMN and SDGs. 
Table 1. Convergence of RPJMN (2015-2019) and SDGs (2015-2030)

\begin{tabular}{l|l|l|}
\hline No. & \multicolumn{1}{|c|}{ RPJMN } & \multicolumn{1}{|c|}{ SDGs } \\
\hline 1. & $\begin{array}{l}\text { Ensuring the country can protect the people and provide } \\
\text { security to all citizens. (10 actions) }\end{array}$ & Goals 9-10, 13 and 16-17 \\
\hline 2. & $\begin{array}{l}\text { Establishing clean, efficient, democratic, and reliable } \\
\text { governance. (5 actions) }\end{array}$ & Goals 5, 10 and 16-17 \\
\hline 3. & $\begin{array}{l}\text { Indonesia builds from the periphery to strengthen the } \\
\text { localities and villages within the framework of a unitary } \\
\text { state. (3 actions) }\end{array}$ & Goals 1-12 \\
\hline 4. & $\begin{array}{l}\text { Strengthening the country's presence by reforming the law } \\
\text { enforcement system and ensuring it is corruption-free, } \\
\text { dignified and reliable. (6 actions) }\end{array}$ & Goals 5, 10 and 14-16 \\
\hline 5. & $\begin{array}{l}\text { Improving the quality of human life and society in } \\
\text { Indonesia. (5 actions) }\end{array}$ & Goals 1-4, 6, 8 and 10 \\
\hline 6. & $\begin{array}{l}\text { Improving productivity and competitiveness in the } \\
\text { international market. (11 actions) }\end{array}$ & Goals 8-11 and 17 \\
\hline 7. & $\begin{array}{l}\text { Realising economic independence by moving strategic } \\
\text { sectors of the domestic economy. (9 actions) }\end{array}$ & Goals 2, 6-9 and 12-15 \\
\hline 8. & A revolution in national character. (1 action) & Goal 4 \\
\hline 9. & $\begin{array}{l}\text { Strengthening diversity and cultural restoration in } \\
\text { Indonesia. (1 action) }\end{array}$ & Goals 5, 10 and 16-17 \\
\hline
\end{tabular}

Source: Rassanjani (2018)

Although there are some differences, these are not significant, and a high convergence can be found between RPJMN and SDGs. In Chapter 3.4 of the RPJMN document, it is noted that SDGs are a reference to bringing the national development agenda to a global context. In the case of Indonesia, it is clear the SDGs are not just a foreign invention imposed on the national development programme. In contrast, SDGs are fully compatible with the agenda Indonesia is working on, and, this can strengthen both Nawa Cita and RPJMN. Therefore, SDGs will be easily integrated into the national development agenda, and these converging agenda will mollify public sceptics who are against the global agenda. T. L. Wanadjaja claimed that if we look deeper at the 17 goals, almost everything is our problem. Therefore, to achieve success in SDGs we must change the notion that SDGs are a global product, and everyone in Indonesia must recognise that SDGs is fulfil our needs (personal communication, June 25, 2017). Thus, the convergence of the national agenda with SDGs will not be detrimental to Indonesia because the 17 development goals listed in SDGs fully represent the needs and ideals of Indonesia. Moreover, Indonesia's involvement in this global agenda offers an opportunity for this country to be more actively involved in international cooperation, as bilateral exchanges with UN agencies and partner countries are very beneficial to Indonesia as a growing country, especially South-South cooperation which has recently been agreed amongst developing countries.

\subsection{A Collaborative-Partnerships}

The SDGs are a massive undertaking that require collaborative-partnerships to succeed; the government cannot operate alone. H. Santono argued that all parties, governments, private companies and society should feel that SDGs are their joint property (personal communication, June 22, 2017). This is because, learning from experience at the time of the 
MDGs, the sense of belonging to this programme is shallow. The government only works alone, while others such as private companies and CSOs were involved but at an insignificant level. And now there is a big hope that, for these SDGs, all parties can become more involved. Learning from the deficiencies of MDGs, the government seeks to improve its performance in the success of SDGs, which will be realised by involving all the relevant stakeholders. In the Table 2 below, the distribution of the four platforms along with their task and function are presented.

Table 2. Indonesian SDGs Platforms

\begin{tabular}{|c|c|}
\hline Government and Parliament & Academician and Expert \\
\hline $\begin{array}{l}\text { Determination of indicators for each } \\
\text { target/goal } \\
\text { Policy, regulation and alignment of } \\
\text { programme/activity development } \\
\text { Data and information setup } \\
\text { Socialisation/dissemination, communication } \\
\text { and advocacy } \\
\text { Monitoring-evaluating and reporting } \\
\text { Funding }\end{array}$ & $\begin{array}{l}\text { Capacity building } \\
\text { Monitoring and evaluation } \\
\text { Policy research }\end{array}$ \\
\hline Philanthropy and Business & CSO and Media \\
\hline $\begin{array}{l}\text { Advocacy to business actors } \\
\text { Facilitate programme/activity to business } \\
\text { actor } \\
\text { Capacity building } \\
\text { Funding support }\end{array}$ & $\begin{array}{l}\text { Dissemination and advocacy to the } \\
\text { community } \\
\text { Facilitate programme/activity in the field } \\
\text { Building public understanding } \\
\text { Implementation and monitoring }\end{array}$ \\
\hline
\end{tabular}

Source: Documents obtained from T. L. Wanadjaja (2017)

Each platform has a role according to their capacity and capability, and all can support one another. The government, as the holder of full control over the passage of a policy, has achieved a great deal, such as appointing BAPPENAS as the main institution responsible for managing the SDGs road map, which is in line with the national agenda of RPJMN. Various development programmes and SDG regulations can be monitored directly by the community in the secretariat that has been established through the official website (www.sdgsindonesia.or.id).

Several prominent universities such as the University of Indonesia, Padjadjaran University, Brawijaya University, and Bogor Agricultural Institute have established the Centre of Excellence of SDGs. Thus far, Padjadjaran University seems to be the most serious in supporting SDGs, and have allocated their resources accordingly as can be seen on their website (www.sdgcenter.unpad.ac.id). This includes various research publications related to social policy, and social content in the form of news, posters, and videos. Other educational institutions, however, do not have an official website that directly oversees the SDGs.

Meanwhile, other platforms such as Civil Society Organisation (CSO) and Media have also been actively playing a role in this initiative. Information related to SDGs has also been scattered across the media, both print and electronic, and is easy to access by the society. At the same time, several CSOs have taken part in the SDGs, such as INFID (www.infid.org) and Kemitraan (www.kemitraan.or.id), who have both advocated SDGs in different ways, 
such as via research, press releases, and so on. M. S. Saraswati explained that I have witnessed the CSOs becoming more active in these SDGs than the government itself. For example, in Bali, there is a plastic-movement that has enabled me to know a lot more about SDGs (personal communication, July 09, 2017). Thus, both the media and CSO play an important role in presenting the programme to the wider community.

Philanthropists and business actors are also eager to help the government, and have consolidated internal coordination by establishing a special body known as Philanthropy and Business Indonesia for SDGs (FBI4SDGs). Currently, FBI4SDG comprises 11 associations with more than 700 companies as its members. Initially, the Platform held regular monthly meetings to coordinate and share information, as well as actively participating in disseminating SDGs amongst business actors, and organising workshops enabling members to better understand the SDG action plan. Furthermore, all information and progress measures made by this platform have been published publicly on the website (www.filantropi.or.id).

If these four platforms can mutually work together to support the achievement of SDGs then automatically this will be an indicator of the potential attainment of Goal 1, -it's a dream to achieve Goal 1, and other goals that follow will not be too difficult (T. L. Wanadjaja, personal communication, June 25, 2017). Based on internet document tracking, it can be said that only Indonesia appears to have this kind of partnership supporting the SDGs. Furthermore, these four existing platforms must be maximised to improve coordination and cooperation across sectors, from planning, policy-making, implementation, monitoring, and reporting through to evaluation.

\subsection{Well-Established Poverty Reduction Program}

The Government has undertaken a series of efforts to accelerate poverty alleviation in Indonesia, and one of these is by establishing a national social protection system. V. Yulaswati argued that one of the pillars of poverty reduction is a comprehensive social protection programme, and now some of the priority programmes are well-established by the government (personal communication, July 19, 2017).

One of indicators of the SDGs mentioned that "the proportion of the population covered by social protection floors/systems, the categories of which include gender, children with special needs, unemployed persons, older persons, persons with disabilities, pregnant women, new-borns, work-injury victims and the poor and the vulnerable" (Target 3 of Goal 1). And social protection programme entitled Program Keluarga Harapan (PKH) is already covered almost of group that mentioned above. Participants in PKH are low-income families with a health component (pregnant, postpartum, new-borns, preschool), compulsory education component (primary, junior and senior high school) or are children aged 6-21 years who have not completed compulsory education, a severe disability component, and an elderly (over 70 years) component. Internationally, this type of social protection is known as Conditional Cash Transfers (CCT), and for some countries, the programme has proved quite successful in tackling chronic poverty. One of the countries with the best record in this regard is Mexico. The success of the CCT programme in Mexico has drawn particular attention from international development organisations such as the World Bank, which ultimately 
encourages other developing countries in the world to introduce similar types of poverty reduction policy (Uchiyama, 2017).

Furthermore, PKH has been implemented continuously since 2007 in seven provinces, and in 2016, it has been implemented in 34 provinces covering 6 million low-income families in 514 districts/cities. Furthermore, it can be seen from the figure 1 below that the number of programme beneficiaries each year is increasing, demonstrating that the government continues to make improvements to expand the welfare of the poor in Indonesia.

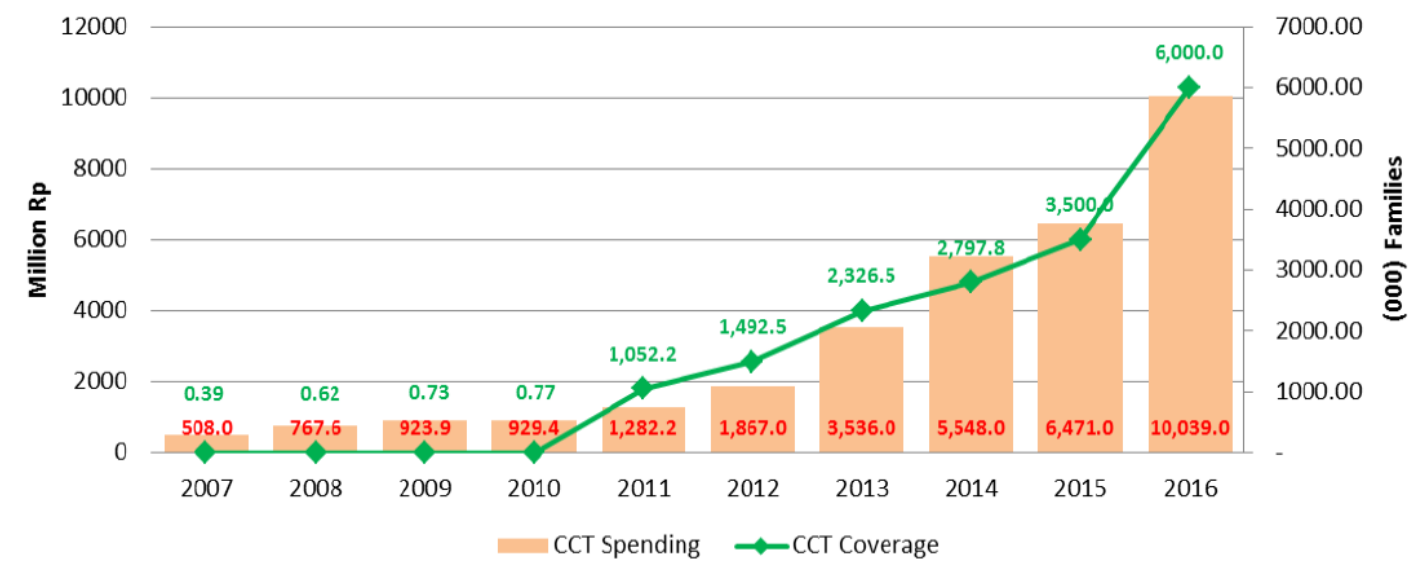

Figure 1. PKH Realisation 2007-2016

Source: Ministry of Social (2017)

Although classified as a long-term programme, $\mathrm{PKH}$ membership is not permanent, and last for just for six years. Therefore, within that timeframe, it is expected that PKH participants will experience an increase in socioeconomic status, as well as behavioural changes in health and education. Moreover, recertification will take place in the fifth year, and families whose standard of living has increased and no longer qualify as recipients are deemed to have graduated and are automatically excluded from membership. However, if it is not considered feasible to graduate, there is a transition programme in last three years. The participants of PKH will then be provided with a family capacity building meeting called Pertemuan Peningkatan Kemampuan Keluarga (P2K2) which contains information about activities and economic-based complementary programmes as well as integrated and relevant social protection programmes to help them to improve their welfare and capacity to be self-reliant.

V. Yulaswati said that if I am asked; has Indonesia built a national social protection programme for all? At the very least, government efforts are sufficient in the context of comprehensive social protection by the RPJMN (personal communication, July 19, 2017). Thus, Target 3 (social protection systems) of Goal 1 (no poverty), which is measured by indicators in line with the provisions of UNDP, has been run by Indonesia since before the SDGs were implemented.

\subsection{Alternative Funding Like Zakat}

SDGs are a massive programme that require a huge budget, so the government need an 
alternative source of money. C. R. Ratri argued that funding is a classic problem because inevitably SDGs require a lot of operational costs. It is a matter that needs to be arranged from the start so that a programme does not stop in the middle of the road due to lack of funds (personal communication, July 08, 2017). Moreover, T. L. Wanadjaja added that each goal, with each target and its associated indicator, requires a great deal of funding, especially Goal 1: planning to alleviate poverty, and I am sure that the state budget owned by the government will not be enough to realise every target and indicator. This is where other sources of funding can be obtained, from platforms that can be invited to cooperate (communication, June 25, 2017).

A strong sense of ownership involving partnerships and collaborations between the government, private sector and civil society can be a great source of strength in the success of the SDGs, and one important factor may be the involvement of religious organisations. In everyday life, faith-based organisations always disseminate human values such as helping each other through charity. In the Islamic social protection system, there is a term known as Zakat which refers to donations. According to a study conducted by Ahmed (2008), Zakat is believed to produce economic prosperity for society because zakat is theoretically paid from those who have advantages to those who have shortcomings. Moreover, Zakat also plays its role as a financial mechanism, which runs some of the major functions of modern public finance related to social security, social assistance grants for childcare, food subsidies, education, health care, housing, and public transportation (Yusoff and Densumite, 2012). Thus, Zakat aims to provide services and benefits that will play a major role in eradicating poverty and hunger. Moreover, the existence of Zakat can increase prosperity because it will help to restore and improve the purchasing power of the poor and will provide other social needs.

The majority of Indonesians are Muslim and believe in paying Zakat even though this is not seen as a duty of citizens, although Muslim countries such as Libya, Malaysia, Pakistan, Saudi Arabia, Sudan, and Yemen all enforce the collection of Zakat (Powell, 2009). The potential of Zakat in Indonesia to support the activities of SDGs is enormous, data provided by BAZNAS (2017) from 2002-2015 in Table 3 shows that the average increase in Zakat growth reached 39.28 percent, this is greater than the mean GDP growth of only 5.42 percent.

Table 3. Zakat Collection in Indonesia (2002-2015)

\begin{tabular}{c|c|c|c|c}
\hline Year & IDR (Billion) & GBP (Million) & Annual Growth (\%) & GDP Growth (\%) \\
\hline 2002 & 68.39 & 3.97 & - & 3.7 \\
\hline 2003 & 85.28 & 4.96 & 24.70 & 4.1 \\
\hline 2004 & 150.09 & 8.72 & 76.00 & 5.1 \\
\hline 2005 & 295.52 & 17.17 & 96.90 & 5.7 \\
\hline 2006 & 373.17 & 21.69 & 26.28 & 5.5 \\
\hline 2007 & 740 & 43.00 & 98.30 & 6.3 \\
\hline 2008 & 920 & 53.46 & 24.32 & 4.9 \\
\hline 2009 & 1,200 & 69.74 & 30.43 & 6.1 \\
\hline 2010 & 1,500 & 87.17 & 25.00 & 6.5 \\
\hline 2011 & 1,729 & 100.48 & 15.30 & 5.23 \\
\hline 2012 & 2,200 & 127.85 & 27.24 & 5.02 \\
\hline 2013 & 2,700 & 156.90 & 22.73 & 4.79 \\
\hline 2014 & 3,300 & 191.77 & 22.22 & \\
\hline 2015 & 3,700 & 215.01 & 21.21 & \\
\hline
\end{tabular}


Source: BAZNAS (2017)

Recent data indicates there is a substantial gap between the potential of Zakat and the realisation of its collection. According to BAZNAS (2017), the potential of national Zakat should have reached IDR 286 trillion (GBP 16.62 billion) by 2015, a figure generated using the extrapolation method in relation to GDP growth in previous years. However, this potential is not yet supported by the optimisation of Zakat funds accumulated in the field, which means that the figure of IDR 3.7 trillion (GBP 215.01 million) is only 1.3 percent of its potential. We are also focusing on improving Zakat's more targeted distribution because Zakat can also be included amongst the essential pillars of SDGs. Zakat potentially is very large, in the year 2016 it collected 2.6 trillion but actually it can reach 268 trillion (T. L. Wanadjaja, personal communication, June 25, 2017).

The World Zakat Forum (WZF) conference, held in Jakarta in March 2017, spawned 11 points of resolution and one of these is related to SDGs. That point is the fifth resolution, which stated that the SDGs as indicators of global welfare can be synergised with Zakat in improving people's welfare. Further discussion is therefore needed on the implementation of SDGs (WZF, 2017). Thus, there is a significant linkage between, and interest among, Zakat organisations to pursue SDGs even further, because there are some clear links between SDGs and Zakat. Also, many items listed in the SDGs reflect Islamic values, such as reducing poverty and hunger, and lessening the inequality gap by sharing wealth, goals which are in line with the principles of Zakat in Islam.

\subsection{Data Innovation}

Audibert et al. (2017) stated that "... comprehensive data is needed to fully understand the impact of existing policies or the productivity of an innovation, but to collect real data to measure the progress of a programme poses many challenges". Moreover, Law Number 25, Year 2004 on the National Development Planning System section 31 also mandated the use of data in a development plan stating, "the development planning has to be based on accurate and accountable data and information".

T. L. Wanadja claimed that Indonesia at this early stage will not directly succeed in reaching all targets and indicators. This is because Indonesia does not have sufficient databases to record it all; to calculate the extent to which an achievement meets 169 targets and 241 indicators requires data and, so far, the BPS cannot ensure sufficient data space will be available (personal communication, June 25, 2017). In addition, there are many obstacles related to the amount of data we need, especially in the process of updating, verification, and validation. This is because the data is very dynamic, for example there is one family that initially did not have a member with a disability, suddenly there was an accident and now they have family members who are disabled, but the data is not updated so they do not get related social assistance (V. Yulaswati, personal communication, July 19, 2017).

Thus, the unavailability of a relevant poverty database has led to the ineffectiveness of poverty alleviation programmes, and this is one of the fundamental problems because the data accuracy of programme targets will have a direct impact on their success in achieving poverty 
reduction and meeting vulnerability objectives. Moreover, the poverty programme itself comes in many varieties, and the characteristics of poverty in each region also vary, so that often the data needs that match the programme targets are not available. Even if the data is available, most of it is irrelevant, and future updates and validations are in doubt. Therefore, it is crucial to improve the accuracy of programme targets by ensuring the availability of a potential database of programme beneficiaries.

V. Yulaswati explained that now the government started to build a unified database which called Basis Data Terpadu (BDT) containing data by name and address of $40 \%$ of lower-income data (personal communication, July 19, 2017). Building BDT is one of the efforts undertaken by the government to solve data problems. Currently, BDT has become the reference data for all poverty reduction programmes, both social assistance programmes and social protection programmes. BDT is designed as the basis for the integration and synchronisation of many social protection programmes, so it is expected to be used for all poverty reduction programmes at both national and local levels. Therefore, the adoption of this integrated approach (one data source) will reduce overall administrative costs, as each application does not need to allocate its resources to this activity, thus resources can be channelled to address other issues related to socialisation or implementation.

\subsection{Learn from Best Practice}

To achieve significant success in terms of the achievement of SDGs, Nicolai et al. (2015) said that achieving remarkable progress in a relatively short period is the dream of every country, and it is most likely to be achieved by learning from the experiences of other nations. Moreover, program adoption or replication is necessary, also, more success stories are needed as awareness raisers for the wider community (personal communication, August 01, 2017). Studying the experience of other countries is certainly a good idea, and it is proved itself by the government when implemented social assistance programmes such as $\mathrm{PKH}$ which cannot be divorced from the influence of Mexico's success in implementing CCT as already discussed above.

Considering that SDGs in the new global agenda have been applied since last year, it is difficult to find the best example amongst implementing countries. Perhaps the best example currently capable of representing SDGs is the achievement of the last joint global agenda which focused on the success of MDGs. According to UNDP (2015), "China is an outstanding country that has performed very well in terms of the MDGs; although not all targets and indicators were achievable, at least China has made tremendous progress in poverty reduction, and in improving basic education and health needs. One of the main reasons behind China's success is that it has successfully aligned national development goals with the MDGs". If, eventually, Indonesia uses China as a reference, then the next step is to choose one of the potential local governments in Indonesia to serve as a pilot project.

H. Santono believed that local governments are the spearheads that can achieve SDGs. So here we hope that many local governments can serve as an example of success for other local governments (personal communication, June 22, 2017). Overall, Indonesia has 514 cities/regencies spread over 34 provinces. In terms success and failure, budgeting and so on, a 
trial programme cannot be applied directly to all regions because it will be a risk. Therefore, it will require several local governments to test the programme for a couple of years, and if it works well the pilot can be rolled out to all provinces in Indonesia.

\section{Conclusion}

Poverty has long haunted Indonesia, and inflation shocks that have occasionally attacked the country are believed to be the main reason why Indonesia still cannot escape from the shackles of poverty. Although, statistically, the number of poor people in Indonesia continues to show a decline, the absolute number of poor people in Indonesia is still very high. Moreover, several subsidies through social protection programmes have been launched to help alleviate the burden of the poor, but there are still many obstacles in the field, such as data problems that result in most of the aid being poorly targeted. Nevertheless, the government remains serious about dealing with poverty and various steps and innovations are continuously pursued, one of which is to be actively involved in a series of global development agendas co-hosted with other UN member states.

The MDGs (2000-2015) which aimed to halve poverty, were Indonesia's first valuable global experience; although they were not perceived as having been entirely successful, at least during that period Indonesia has reduced its poverty rate by nearly half, from $19.14 \%$ to $11.13 \%$ (BPS, 2018). Furthermore, Indonesia's second chance to continue what remained unresolved in the MDGs is present in the SDGs (2015-2030), and this post-2015 development agenda is more ambitious than the MDGs in targeting zero poverty by 2030 . Governments and experts argue that the SDGs are currently the most sophisticated development programme, and feel optimistic in believing it will improve the well-being of societies around the world.

There are six factors that might influence the achievement of SDGs, namely; converging of agendas, collaborative-partnerships, well-established poverty reduction program, alternative funding through Zakat, the innovation of databases, and learning from best practice. There are many similarities between the national development agenda (RPJMN) and SDGs, which is beneficial to the Indonesian government as they do not need to change the course of national development planning, just synergise the two. Moreover, the governments are trying to cultivate a sense of ownership and shared responsibility for SDGs by forming joint collaborations across four platforms, namely; government and parliament, academia and experts, civil society and the media, and philanthropy and business. These four platforms are complementary to each other in terms of their duties and functions, and their existence provides unique value to the implementation of SDGs in Indonesia.

Referring to Goal 1-Target 3, Indonesia already has a well-structured social protection system "for all". Its social assistance programmes have accommodated; pregnant women, new-borns, children, older persons, and individuals with disabilities through the $\mathrm{PKH}$ programme. Moreover, considering that the SDGs have a significant number of goals and targets, the central budget government has at its disposal will not be enough to cover the needs of each goal and target, not to mention the fact that the government will travel a long journey of fifteen years to complete the SDGs. Therefore, it is important to find alternative funding so 
that the programme does not stop in the middle of implementation due for financial reasons, and it is likely that the Zakat is the resource most capable of compensating for any shortfalls in budgets. First, the Zakat shares the same values as SDGs regarding the welfare of mankind; Secondly, Indonesia is a country with a high population and the majority of its people are Muslim, thus there is a potential for Zakat collection, if managed properly, to deliver funds exceeding the annual state budget; Finally, the World Zakat Forum itself has this year declared 11 resolutions to be achieved in the near future, and one of these involves helping member countries to succeed in the pursuit of SDGs. Moreover, aside from constrained funds, the government is also overwhelmed with poverty data, given that Indonesia has many residents spread over thousands of islands. The absence of accurate data has caused poverty alleviation to be misaligned, although several years ago the government developed a unified database called BDT which is expected to solve such data problems.

The final factor that might influence the achievement of SDGs concerns learning from best practice. Amongst many countries, China is a country that provides Indonesia with the best example for reaching SDGs in the future. For example, Indonesia can take note of the achievement of the MDGs, where China succeeded in synergising national development goals 'Xiaokang' with global development. This step can therefore be imitated by Indonesia, by synergising 'Nawa Cita' with the SDGs.

Although the Indonesian government has made many efforts in the implementation of SDGs, there will be many obstacles that present a significant challenge to their success. Thus, the six factors mentioned above may provide the ideal solutions to some crucial difficulties that will be faced, and the success of the MDGs should be a valuable lesson enabling Indonesia to work more optimally to achieve the SDGs. Moreover, in line with one its main principles "no one left behind", the SDGs provide the widest opportunity for every country to continue to work together in the fight against poverty. Furthermore, this is also a golden opportunity for Indonesia to learn from the many experiences of developing countries in this global cooperation scheme, and optimise all the Goals-Targets-Indicators of SDGs and finally achieve "zero poverty" in 2030.

\section{Acknowledgement}

I will never forget to give all of my gratefulness to Lembaga Pengelola Dana Pendidikan (LPDP) for the scholarship that funds my study and research at the University of Glasgow.

\section{References}

Ahmed, H. (2008). Zakat, Macroeconomic Policies, and Poverty Alleviation: Lessons from Simulations on Bangladesh. Journal of Islamic Economics, Banking and Finance, 4(2), 83-111.

Audibert, C. et al. (2017). Building a Drug Development Database: Challenges in Reliable Data Availability. Drug Development and Industrial Pharmacy, 43(1), 74-78. https://doi.org/10.1080/03639045.2016.1220565

B.P.S. (2018). Profile of Poverty in Indonesia September 2017. BPS. [online] Available at: <https://goo.gl/uaFfpR> [Accessed 14 May 2018]. 
BAZNAS. (2017). Indonesia Zakat Outlook 2017. puskasbaznas. [online] Available at: <https://goo.gl/gD2giY> [Accessed 26 July 2017].

Bryman, A. (2012). Social Research Methods. New York: Oxford University Press.

Kamruzzaman, P. (2016.) A Critical Note on Poverty Eradication Target of Sustainable Development Goals. European Journal of Sustainable Development, 5(2), 87-110.

Kumar, S. et al. (2016). Millennium Development Goals (MDGS) to Sustainable Development Goals (SDGS): Addressing Unfinished Agenda and Strengthening Sustainable Development and Partnership. Indian J Community Med, [online], Volume 4, 1-4. Available at: <https://goo.gl/aF4Fqy> [Accessed 09 May 2017].

Liu, Q. et al. (2015). Poverty reduction within the framework of SDGs and Post-2015 Development Agenda. Science Direct, [online] Volume (6), 67-73. Available at: <https://goo.gl/VGuBae> [Accessed 11 June 2017].

Lueddeke, G. (2015). Towards an Integrative Post-2015 Sustainable Development Goal Framework: Focusing on Global Justice-Peace, Security and Basic Human Rights. SEEJPH. [online] Available at: <https://goo.gl/8V435w> [Accessed 01 July 2017].

Maxwell, J. (1997). Designing a qualitative study. In: L. Bickman, and D. Rog, ed., Handbook of Applied Social Research Methods. California: Sage Publication, 69-100.

Ministry of Social of Indonesia Republic. (2017). The Implementation of Program Keluarga Harapan (PKH). PKH Jogja, [online] Available at: <https://goo.gl/NUhR6z> [Accessed 20 July 2017]

Nicolai, et al. (2015). Projecting Progress: Reaching the SDGs by 2030. Overseas Development Institute. [online] Available at: <https://goo.gl/1T5PGq> [Accessed 29 June 2017]

Onditi, F., \& Odera, J. (2016). Gender Equality as a Means to Women's Empowerment? Consensus, Challenges and Prospects for Post-2015 Development Agenda in Africa. African Geographical Review, 36(2), 146-167. https://doi.org/10.1080/19376812.2016.1185737

Patton, M. (2002). Qualitative Research and Evaluation Methods. London: Sage Publications.

Powell, R. (2009). Zakat: Drawing Insights for Legal Theory and Economic Policy from Islamic Jurisprudence. University of Pittsburgh Tax Review, 7(43), 43-101.

Proulx, K., Ruckert, A., \& Labonté, R. (2017). Canada's Flagship Development Priority: Maternal, Newborn and Child Health (MNCH) and the Sustainable Development Goals (SDGs). Canadian Journal of Development Studies, 38(1), 39-53. https://doi.org/10.1080/02255189.2016.1202103

Rassanjani, S. (2018). Sustainable Development Goals (SDGs) and Indonesian Housing Policy. Otoritas: Jurnal Ilmu Pemerintahan, 8(1), 44-55. https://doi.org/10.26618/ojip.v8i1.760

Salleh, A. (2016). Climate, Water, and Livelihood Skills: A Post-Development Reading of the SDGs. Globalizations, 13(6), 952-959. https://doi.org/10.1080/14747731.2016.1173375

Scott, J. (1990). A Matter of Record: Documentary Sources in Social Research. Cambridge: Polity. 


\section{Macrothink}

Journal of Public Administration and Governance ISSN 2161-7104 2018, Vol. 8, No. 3

Uchiyama, N. (2017). Household Vulnerability and Conditional Cash Transfers: Consumption Smoothing Effects of PROGRESA-Oportunidades in Rural Mexico, 2003-2007. Tokyo: Springer Nature. https://doi.org/10.1007/978-981-10-4103-7

United Nations Development Program. (2015). Discussion Paper on China, the Millennium Development Goals, and the Post-2015 Development Agenda. UNDP CHINA. [online] Available at: <https://goo.gl/dRVsaK> Accessed [03 August 2017].

United Nations. (2000). Goals, Targets, and Indicators. United Nations. [online] Available at: <https://goo.gl/gDq3qc> [Accessed 09 May 2017].

United Nations. (2017). Revised List of global Sustainable Development Goal indicators. United Nations. [online] Available at: <https://goo.gl/tJgdu2> [Accessed 29 June 2017].

Weitz, N., Nilsson, M. and Davis M. (2014). A Nexus Approach to the Post-2015 Agenda: Formulating Integrated Water, Energy, and Food SDGs. SAIS Review of International Affairs, 34(2), 37-50. https://doi.org/10.1353/sais.2014.0022

World Bank. (2013). Rural-Urban Dynamics and the Millennium Development Goals. World Bank. [online] Available at: <https://goo.gl/f2ru46> [Accessed 09 May 2017].

World Zakat Forum. (2017). 11 Points of Resolution World Zakat Forum Conference. World Zakat Forum. [online] Available at: 〈https://goo.gl/2cSgBF> [Accessed 26 July 2017].

Yusoff, M., \& Densumite, S. (2012). Zakat distribution and growth in the federal territory of Malaysia. Journal of Economics and Behavioral Studies, 4(8), 449-456.

Indonesian Legislation and Document

Law Number 25 Year 2004 on National Development Planning System. [online] Available at: <https://goo.gl/B5SYD5> [Accessed 26 July 2017].

Document of Rencana Pembangunan Jangka Menengah Nasional (RPJMN) 2015-2019. [online] Available at: <https://goo.gl/NpaGU9> [Accessed 20 July 2017].

\section{Copyright Disclaimer}

Copyright for this article is retained by the author(s), with first publication rights granted to the journal.

This is an open-access article distributed under the terms and conditions of the Creative Commons Attribution license (http://creativecommons.org/licenses/by/4.0/). 